\title{
Father Figures in the Novels of Jane Austen
}

\author{
Dr. Adli Odeh \\ Al-Dawadmi Community College, Shaqra University \\ POBox: 18, Al-Dawadmi 11911, KSA \\ Tel: 966-55-91-32307 E-mail: dr_adli66@hotmail.com
}

Received: January 6, 2011 Accepted: January 28, 2011 doi:10.5539/elt.v4n2p35

\begin{abstract}
Miniaturist as Jane Austen is, she has depicted the life of a few families. In her letter to her niece, Anna Austen, she writes: "three or four families in a country village is the very thing to work on"(Chapman's Edition, 1970, P.10). Jane's knowledge about these families is, in no way shallow. It is rich in variation and contrasts. Jane Austen is a great novelist due to the universal significance of her novels. This universal significance is achieved in two ways. First, she creates living characters; she penetrates beneath the surface to the underlying principles of personality. She has a full understanding of human psychology and this enables her to draw intricate and complex natures. She lays bare not only the processes of their minds but also those of the heart. Second, she considers them impartially and shows them compounded both of faults and virtues like human beings. They have a universal significance; they are not national types, but representatives of essential human nature. They reveal the weaknesses and virtues of human nature in every age and country. There has been insufficient attention focused on Jane Austen's father figures: how she created characters and what character types and father figures emerge in the full range of her stories. Characters are centre front in her stories, many of which are chiefly fine vignettes, and in Austen's theoretical statements she has consistently stressed the importance of character creation. The objective of this research is to shed light on those father figures who are the heads of the central families in Jane's six novels.
\end{abstract}

Keywords: Father Figure, Novel, Jane Austen, Character Portrayal

\section{Introduction}

Jane Austen shows an intuitive understanding of human characters. Her intuition is so natural and supple that it appears absolutely simple. She reads the inner minds of her character as if those minds were transparent. She seizes them in their depths. The secret complexities of self-love, the many vanities, the imperceptible quivering of selfishness, are all indicated or suggested so calmly and with so sober touch a touch that the author's personal reaction is reduced to a minimum. Her stories are perfectly objective and they show a spirit of gentle tolerance, though a subtle suggestion of irony hovers over every page and reveals a sharpness of vision that could be extremely severe.

Her novels contain a wealth of character studies. These character studies are not all equally good. For example the character of Mr. Bennet is not like the character of General Tilney in the treatment of their families. But it is very much obvious that Austen studies of women characters are more searching and more life-like than those of men. She has delineated character from the inside with the full and finished touch of the great masters; and she can also sketch figures with so sure and suggestive a pen that they stand out on a strong and unforgettable ground. Her power of perception is keen and fresh. She immediately grasps the individual traits, the odd as well as the comic. Her work represents in an original way the internal comedy of life with all its whims and fancies. Reality awakens in her a spirit of amusement without bitterness. Her grasp of character does not destroy the concrete sense of faces, gestures, and acts.

Another trait that Jane Austen possesses with regard to character portrayal is the power to create living characters. It true that she only draws them in their private aspect, but this is not a superficial aspect. A man's relation to his wife and children is at least as important a part of his life as his relation to his beliefs and career; and reveals him as fundamentally. Indeed, it reveals his moral side more fundamentally. If we want to know about a man's talents, we should see him in society; if we want to know about his temper, we should see him at home. Furthermore, Jane Austen shows man as a rule not in moments of crisis but in the trivial incidents of every day. After all, life is made up of little things, and human nature reveals itself in them as fully as big ones. A picnic shows up selfishness, kindness, vanity, sincerity, as much as a battle. Only we must have the faculty to perceive them. Jane Austen had this faculty. Not Dickens himself can visualize outward idiosyncrasies of his creature more vividly, their manners, their 
charm, their tricks of speech. But she does not have to present man involved in major catastrophe. However, if her plot demands it, she shows adequate capacity for portraying her characters in moments of serious crisis.

Jane Austen's range of character is very large. She painted on such a narrow canvas that people have not always realized this. But a wide canvas does not necessarily mean a wide range. Thackeray painted on a vast canvas, but his range of characters is small, for he always repeats them; his good women are always pictures of the same person in a different dress. Jane Austen good men are all different. In her six novels, she never repeats a single character. Moreover, her interest in human motive, the reactions of individuals to each other; and therefore a narrow social setting was an ideal material for her. The small area of experience allowed closer analysis of recurring situations and types; she could deal with them with absolute accuracy by never stepping beyond the limits of her personal knowledge.

There are other reasons for the vitality of her characters. Her eye for the surface of personality is unerring. She can visualize the external of personality as vividly as Dickens himself. With a few brief sentences, she can bring out the habit, the dress, the appearance, and the tricks of speech. But she does not stop at that. Her discriminating vision can penetrate to the organizing principles of a personality that lie beneath the surface. She can discern the motives and causes of conduct, the essentials of action. Her understanding of human nature is complete. She possesses full knowledge of the head and heart. She presents her figures so wonderfully, that the same person strikes differently to different persons. The result is that her characters are living, breathing realities and not mere puppets or abstractions. They are complex, like human beings, and not mere embodiments of humors like the characters of an inferior kind of drama. Their vitality never runs dry; they are ever revealing new facets of their nature.

Her characters are many-sided; they are mixture of good and evil, virtue and wickedness in varying proportions like real human beings. Jane Austen is impartial; she does not idealize. Her most virtuous characters have their faults. And, what is more striking; she shows how these faults are integral to their natures. They have certain virtues, and these very virtues result in certain faults in their respective characters. The intensity of Jane's vision fuses vices and virtues into a single integrated personality and this "gives her character volume; they are not merely brilliantly drawn silhouettes, but solid, three dimensional figures, who can be looked at from several sides" (Cecil, 19781).

Jane Austen's methods of character presentation are dramatic. The character is developed through short scenes in dialogue. A character reveals himself in his conversation: further light is thrown upon his nature by what others say about him. In this way, a character is examined from various angles, and the various facts of his personality are revealed. Thus the character of the Bennets is revealed in the very first chapter through a dialogue between husband and wife.

\section{Different Types of Father Figures}

Jane Austen is credited with painting "small cameos" of families in her novels. Yet within these cameos, it becomes clear that Austen had a clear understanding of family dynamics as we consider them today. The relationships between parents and the children, the way in which parents raise their children--in Austen's case, the daughters--generally has a major influence on the marriage choices that these daughters make. In the widespread view of parenting styles in psychology created by Diana Beaurind in the 1970's, parents could be classified in one of four ways: authoritarian, authoritative, permissive-indulgent, and permissive-indifferent. Austen's novels show parents whose parenting techniques often varied depending on the child. Therefore, some parents may act one way with the heroine of the novel and another way with the other children in the family.(Newman,A,2009).

This is a theory that has not been used in published research to examine the parents in Austen's novels. In fact, in the studies of Northanger Abbey and Sense and Sensibility, where the parents play little of an actual role within the novel, past critics have had little to say about the parents of the heroines. The critic who has come the closest is Bernard Paris, who examined character and conflict in Jane Austen's novels. In this paper, I will try to examine the role and impact of the parents in general and the father figures in particular in the novels of Jane Austen. (Newman, A, 2009)

Permissive-indifferent parents are very uninvolved in their children's lives. This can come about for a variety of reasons, but the effects on the children are generally the same. The children lack self-control, are socially incompetent, and do not handle independence well. In some ways, they cause more problems than any of the other types of parents because there is usually a lack of love for the children, and thus the children do not learn how to love. Most of the parents in Austen's novels are either completely permissive-indifferent or are so in varying degrees. Mr. Bennet is indifferent to the rest of his children and lives in his library, leaving them to their mother's care and their own devices. Except for his dealings with his favorite daughter, Elizabeth, Mr. Bennet only exposes himself as a parent during the unpleasant business of Lydia's elopement (Mudrick, 1952,p.113). His feelings of inadequacy as a parent following that event disappear as rapidly as he predicts they will, indicating that he knows what is wrong with 
himself but really does not care enough to change.

The Morlands, in Northanger Abbey, are indifferent to their daughter Catherine for a different reason, which is simply that they have no time. Catherine's father is a clergyman, but not a poor or neglecting one as one "might" expect. He is a very respectable man with "considerable independence, besides two good livings" (Northanger Abbey). This is basically all we know about Mr. Morland, except that he does not have a tendency to lock up any of his daughters. While none of the other Austen fathers have had this tendency, as a satire of Gothic novels, this novel might be expected to hint that if he were a Gothic father, he would lock them up.

To begin with, General Tilney may not be the murderer of his wife but he has "an air and attitude" of Montoni, the sinister owner of the castle of Udolpho in Mrs. Radcliffe's novel. He is selfishly an ambitious man. He is an embodiment of mercenariness and greed that Jane hated the most. Like a typical military man, general Tilney has large acquaintance and applies to John Thrope for information regarding the fortunes of Catherine, owing to his sheer sense of greed and his cunningness, he invites Catherine to Northanger Abby in order to make her the pride of Henry. Inviting her to Northanger Abby, he also means to cut her off from John Thorpe. He is capable of speaking shallow and insincere language to Catherine, complimenting her for her grace and her beauty. It sounds insincere due to his sycophantic references to the Allens from whom, as he believes; Catherine is to inherit an enormous fortune. His crude sense of match-making based on mercenary consideration, is evident in the scene when he places Catherine gracefully in Henry's marriage.

It is an odd behavior on the part of the General to have banished Catherine from the Bath on the basis of the same testimony (i.e. of John Thorpe) without feeling the need of verifying his information from other sources. Having learnt that Catherine is no heiress of an enormous fortune, he acts rather villainously and separates Catherine from Henry. Catherine's sufferings start multiplying and her story of distress begins. The pseudo-Montoni, in fact, introduces the element of distress and suffering in the novel. It is here that the general is connected with the second part of the story, the real horrors of the heroine as against the fictional horrors in Northanger Abbey. It is here that the author has, emphatically, shown that the real horrors of life are as horrifying as the fictional horrors or even much more terrifying. Jane has assigned the General, a functional role in the double theme of the story. He plays a vicious but important role in the story, for in Catherine's banishment lies her education in life.

General Tilney's gullibility, in believing the same source regarding the fortunes of Catherine, gives the story an "unlikelier" twist as Robert Liddell opines (1969). This makes the situation unrealistic and General Tilney as a less convincing figure. He does not seem to be a genuine and realistic creation of Jane's mature art. This appear to be a sound criticism against the author to some extent but, in fact, it is a very minor omission on her part for the reason that there appears every likelihood of the General having learnt about the fortunes of Catherine from other sources while he was on his journey to London. Besides this, an eccentric person as he is, the General's gullibility can be justified without further argument.

The general is an odd and eccentric creation in the sense that he dislikes ' the delightful melancholy'of his late wife's favorite walk; he doesn't care for his portrait, though 'very like'. He indulged in a solitary rambles' which do not speak a mind at ease or a 'conscience void of reproach.' He deems himself as careless on such subjects (the size of his dining room) as most people are. (ch. 21). If he were not 'perfectly without vanity, 'he would have ordered new breakfast china of improved manufacture'. (ch. 22), '....though without any ambition of this sort himself', he believed, his gardens unrivalled in the kingdom.'(ch. 22). The general is also a unique portrait of an uncomprehending parent. He exercises great restraint on his children. He is never reliable or dependable' Henry knows him better than to take him at his words or rides to Woolston to notify his housekeeper.'His children know very well that he can't marry unless the General's mercenary motives are fulfilled in their marriage. He reprimands Captain Tilney for wooing a lady of no fortune. But the author loves her young people too much 'to allow any shadow to fall on their fortune' (Chapman, 1970, P.186), and allows Henry to rebel against General Tilney and marry as he likes.

The General is a villainous character. To Catherine, he is agreeable because ' he was tall, handsome', and on the top of it, ' Henry's father'. Jane assigns him some sort of sensitivity in Henry's words; ' His value of her was sincere and if not, permanently, he was truly afflicted by her death.' (ch.24).These words serve as a saving grace for the character of General Tilney.

In Sense and Sensibility, the father figure is missing. Mrs. Dashwood enters the stage as a widow, and we know little of her husband except that the old Dashwood 'invited and received into his house the family of his nephew, Mr. Henry Dashwood, the legal inheritor of the Norland estate, and the person to whom he intended to bequeath it. In the society of his nephew and niece, and their children, the gentleman's days were comfortably spent'. (ch.1). Henry Dashwood survives his uncle no longer and recommended to his son, John Dashwood, the interests of his 
mother-in-law and sisters. To know the character of Henry Dashwood, we might draw inferences, as Chapman puts it(1970,P.184), from the character of Mr. John Dashwood but he is not the chip of the old block as it is revealed from his attitude towards his mother-in-law and his sisters. It is rather in the character of the Dashwood sisters that we can know of good blood in Henry Dashwood as they are not stingy as far as money is concerned and evince no moral failings in themselves.

In the absence of real father figure in Sense and Sensibility, John Dashwood passes of as the figure head of the central family of Dashwood. He is unworthy son of unworthy father. The discussion scene between the husband and wife in the second chapter is a brilliant satire on the part of the author on hen-pecked husbands, like john Dashwood whose character is adversely moulded by their domineering wives. John Dashwood is not as bad as he appears later on when he is completely vanquished by his wife's logic, suiting her own purpose. John Dashwood's words: ' show that he has good intentions to help them and that he was basically a good man. His wife's arguments and emotional appeals: ' ... he could not have thought of begging you to give away half your fortune from your own child ... what brother on earth would do half as much for his sisters, even if really his sisters...'bring about a change in him: They can hardly expect more: (same ch.). From here onwards, submissive as he is to his wife and mother, he attempts to satisfy his own conscience by entertaining expectations that other people should provide for his half-sisters. He would have been a different character, had Mrs. John Dashwood not been his life-partner. This is what Jane obviously points out in her presentation of an interesting character like John Dashwood. Their marriage is, in Jane's opinion, not a marriage of true minds. This is also true in case of younger generation throughout Jane's other novels.

Authoritative parents are nurturers. They allow their children to assist in setting limits and controls on their behavior, and there is much give-and-take within their relationship. Authoritative parents truly love their children. As a consequence, the children of authoritative parents tend to be happier, socially and emotionally well-adjusted, and are more socially responsible and competent.

Mr. Bennet is another interesting study of a father figure: Mr. Bennet was so odd mixture of quick parts, sarcastic, humor, reserve and caprice, that the experience of three and twenty years had been insufficient to make his wife understand his character (Pride and Prejudice, The Modern Library Edition.ch.1, p.232). Mrs. Bennet was a woman of 'mean understanding' and as such there appear a dichotomy between the two, they are poles apart. Mr. Bennet appears to have fallen in love with a beautiful woman and learns too late that he has lowered himself into an abyss of folly by marrying a shallow, selfish and an opportunist lady like Mrs. Bennet. Here also Jane seems to opine that Mr. Bennet would have been different, had he married a lady possessing understanding and depth of mind. As it is, Mr. Bennet humors away his life which is made so uninteresting and dull by his wife. He has thus added satirical humor into the novel and become a significant character in the novel.

Mr. Bennet's irony is peculiar, he is an ironist to whom it is not clear as to what 'is' and what merely 'seems'. Irony in him is a mode of escape from the fundamental problems and responsibilities of home life for, he is highly irresponsible father. Even when he sees things clearly, he can't act, rather he 'will not' act. He is dramatized by the author in such a way that he is the last to participate, "let her be called down, she (Elizabeth) shall hear my opinion, .... and last to act: 'an unhappy alternative is before you ... your mother will never see you again if you don't marry Mr. Collins, and I'll never see you again if you do"(Pride and Prtejudice, ch.20, p.299). This is how he performs! He is conspicuous by his detachment, detachment from his house (confined in his library most of his time), and detachment from the story of the novel. He does not contribute towards the development of the plot in any way. He is given to comment as an outsider. He wishes, 'her' daughters to have rich husbands that Mrs. Bennet desires. He gives complete liberty to his children and allows Lydia to go Brighton from where she elopes, Elizabeth becomes worth two fathers to him saying: "if you, my dear father, will not the trouble of checking her exuberant spirit, and of teaching her that her present pursuit are not to be the business of her life, she will soon be beyond the reach of amendment"(Ibid, ch.41, p.369-70). When Elizabeth points out to that they "sisters" will be involved in disgrace, (Lydia's elopement) he seems to echo author's views on the matter: 'Do not make yourself uneasy, my love. Whenever you and Jane are known, you must be respected and valued.' (same ch. P. 370).

Mr. Bennet realizes his duties as a father and says: "Lizy, I bear you no ill-will for being justified in your advice to me last may, which is considering the event, shows some greatness of mind" (ch.8, p 409). He somewhat changes after Lydia's elopement: "Father is now strict with Kitty. She never goes to balls in society (ch.61, p463), and 'Mary submitted without reluctance' (ch. 61, p. 464). Mr. Bennet has not only been irresponsible father but an irresponsible rather an unjust husband in exposing his wife to the contempt of her children. Talented as Mr. Bennet is, had he used his talents rightly, he might have, as Elizabeth believes, preserved the respectability of his daughters, even if incapable of enlarging the mind of his wife. Like an indifferent father, he speaks slightingly of Catherine and Lydia, never bothering about the consequences of such an ill-treatment of his children. He has no turn for economy. His love of independence has made him live beyond his income, despite the fact that his estate is entailed on Collins. In 
such situation a responsible father should have exerted for providing something before his estate was to be entailed on somebody. But he continues to live under optimistic delusions that he might survive Mr. Collins. In Hertfordshire, we are told, 'Elizabeth had to blush for the impropriety of her family', and impropriety of conduct in Mr. Bennet is a major cause of degradation of the children.

The last of Austen's authoritative parents, Pride and Prejudice's Mr. Bennet, might seem an unusual choice. Critics have labeled him as unfeeling and generally uncaring about his family. With his four other daughters, Mr. Bennet is a permissive-indifferent parent. His relationship with his daughter Elizabeth is based on respect and love. With Elizabeth, Mr. Bennet is a concerned, loving parent--even though he jokes with his wife in the beginning that she has only a little more quickness than her sisters. He does not single out any of the others in that first scene, and the only attention he gives his youngest three daughters is to lump them in one category as the silliest girls in England. Jane is a sensible daughter, just like Elizabeth, but she does not have a realistic view of the world. Elizabeth is the child Mr. Bennet shares his amusement with, and he wants only the best for her.

There are two specific examples of Mr. Bennet's concern for Elizabeth's welfare. The first is following Mr. Collins' proposal. Mrs. Bennet insists on Elizabeth's marrying the man and tries to get her husband to talk some sense into her. Mr. Bennet, when presented with the dilemma, calmly says, "An unhappy alternative is before you, Elizabeth. From this day you must become a stranger to one of your parents--your mother will never see you again if you do not marry Mr. Collins, and I will never see you again if you do" (Pride and Prejudice). Mr. Bennet has long realized that his cousin is a fool and that Elizabeth would never be happy with him; therefore, Mr. Bennet will not comply with his wife's wishes despite the financial security such an arrangement would bring for his favorite daughter and the rest of his family.

The other example is following Mr. Darcy's last proposal. Mr. Bennet believes that Elizabeth has hated Darcy from their first meeting, but Mr. Bennet has been unaware of her change of heart. When Darcy asks for permission to marry Elizabeth, Mr. Bennet fears that she is making a grave mistake and marrying for something less than love. In urging her to be sure of her choice, he reveals a side of himself that he has shown only through contempt--his deep dissatisfaction with the woman he married. Once Elizabeth has been able to convince him that she loves Darcy, Mr. Bennet is able to consent more easily than before, saying, "I could not have parted with you, my Lizzy, to someone less worthy"(Pride and Prejudice). Mr. Bennet frequently indicates that he cares for and guides Elizabeth, and that there is a warm, loving side to him which he does reveal to at least one member of his family.

Mr. Bennet, with all the flaws in his character, is a unique creation of the author. Jane is more sympathetic to him than she is to General Tilney. Moreover, he is more convincing a father figure than the General. There is something of Bennet, the commentator in Jane Austen herself. There are certain negative qualities which the author hated the most and he (Mr. Bennet) doesn't possess them. He is not proud, he is not ambitious, he is not cruel to his children and lastly he doesn't pretend to have principles on account of which he should be proud.

Mr. Bennet had no principle in life, whereas, Sir Thomas Bertram can, at least, talk about high principles and pose to be highly principled man. Mr. Bennet is lazy and irresponsible; Sir Bertram is active and has pretensions to be responsible. He is quick in shifting responsibilities to others whenever an occasion proves him to be responsible. He himself allowed Maria's marriage to take place and in doing so, he had sacrificed the right doing to the expedient. $\mathrm{He}$ is always guided by worldly wisdom and his selfishness as in Maria's case. When Maria's marriage is broken and she wishes to make a come-back to his father's house, Sir Thomas Bertram throws responsibility on her and would not allow her to be at Mansfield Park as he doesn't wish to offer too great an insult to their neighborhood. The most extreme of Austen's authoritarian parents also comes from Mansfield Park. Sir Thomas Bertram benevolently takes Fanny in and raises her, but Sir Thomas is distant in her life, a figure of authority who terrifies her even more than Mrs. Norris. Sir Thomas is the most authoritarian of the parents with his own children as well. Unlike Lady Russell, who persuades and leaves no alternative to Anne, and Mrs. Norris, who overindulges the Bertram girls but mistreats Fanny, Sir Thomas' behavior toward every child is the same.

Mansfield Park is a model of patriarchal order, exemplifying the spirit of hierarchy and the assumption of male primacy over the female. Sir Thomas is the principle patriarchal figure: grave, seeing only what he wants to see. Although he appears as the guardian of what is good and proper, he reveals that he has ethical flaws (Bush, 1975, p. 112-113). His first defect is in permitting his wife to give authority over his daughters to Mrs. Norris. Lady Bertram not only gives her sister a position of power that she should not have, but also inflates her ego and causes her to believe that she is more important that she is. Yet Sir Thomas is not completely blameless, either. He acknowledges at the end of the novel that he should have spent more time overseeing his children and repents at how they turned out under the improper guidance of Mrs. Norris and the ignorance of their mother.

Sir Thomas also is not outwardly affectionate. He does not encourage his children to be close to him. This reserve, 
combined with Lady Bertram's indifference, handicaps his children's moral and social education (Bush, 1975, p.114). Sir Thomas can be a thoughtful, sensitive man, but he lacks human sympathy that is apparent to the world outside (Gooneratne, 1970, p. 112). Although there is a marked change when he returns from his trip to Antigua, it is too late to change the relationships he has with his children. They are adults and are now indifferent to him. Another of Sir Thomas' defects is that he is concerned with outward appearances. He married a beautiful woman with little wit or intellect, but as long as she appears to his credit, he does not care. Following his return from Antigua, Sir Thomas simply asks Maria if she's certain she wants to marry Rushworth, and does not concern himself with much otherwise. Maria is marrying a fine name and a great fortune, and Sir Thomas can accept that, as he should. Yet a caring father would be able to see that Maria is reluctant to marry Rushworth and counsel her against it.

His relationship with Fanny changes following his return, yet it is still an authoritarian approach he uses when trying to persuade Fanny to marry Henry Crawford. Sir Thomas berates her for refusing. His disapproval leaves Fanny no doubt of what he wants, yet with her refusal to marry Crawford, Fanny rightly rebels against his wishes. She knows what he does not--that Crawford openly tried to attract Maria even though she was engaged to another man, then left her abruptly when she expected him to marry her. It is out of his sense of responsibility, a general wish of doing the right, and a desire of seeing all that were connected with him in situations of responsibility that he exerts for the advantage of Lady Bertram's sisters. He resolved to be the 'real and consistent' patron of Fanny after serious deliberation and debates with himself about the consequences. But snobbish as he is, faced with a problem:' How to preserve in my daughters the consciousness of what they are, without making them think too lowly of their cousin to make her remember that she is not 'Miss Bertram ', they still can't be equals. Their ranks, fortune, rights and expectations will always be different.' (ch.1, p. 474). He is, however, consoled by the idea that Fanny, being younger than his daughters, will not exercise her influence on them.

Sir Thomas' sense of decorum, as Edmund tells, is strict. This is why Edmund forbids the arrangements of the theatricals and ask the party not to take liberties in his (Bertram's) absence. To his children, except Edmund, ' their father was not object of love' and his absence is rather a welcome. They are, in fact, relieved of the restraint put on them by their father, and have indulgences within their reach. His absence from Mansfield, at a critical period of the lives of his children, especially daughters, is rather odd. He entrusts them to Mrs. Norris who spoils them by her flattery. He has left for Antigue along with Tom with a hope of improving him. When he returns back Sir Bertram, like the old heathen heroes, after performing their great exploits in a foreign land, offer sacrifices to the gods like them for his safe return by undoing the theatrical arrangement. And by doing this, he shuts out noisy pleasures of the young people. Jane Austen, who liked good acting and shunned bad one, seems to show her indignation against Sir Bertram in this respect. The author seems to tell us that Mr. Yates had met many disagreeable fathers, but not one like him so unintelligibly moral and so infamously tyrannical as Sir Thomas (Mansfield Park, ch.20, p.584).

Sir Thomas plays an important role in the development of the story of Mansfield Park as the heroine of the novel happens to be his protégé. He enters his room as if to 'examine her English and French' and evinces his surprise that there wasn't any fire. He restores fire and 'warmth' to her room ironically calling Mrs. Norris unjust in having deprived Catherine of fire in her room. He has given her protection and warmth and wishes to have his pound of flesh. He means clear commercial terms with Fanny: " His (Crawford's) wishing to marry is recommendatory to me ... you have disappointed every expectation ... I would have bestowed either of my own daughters ... if your heart can acquit you of ingratitude"(Mansfield Park, ch.32, p.661-2). Sir Thomas appears to be in a bargaining mood. He wishes to be paid by Fanny for what he has done for her. When he finds Fanny unyielding, he asks Edmund to exercise his influence on her. When Edmund even fails, he uses what he conceives as, ' medicinal project' by sending her to Portsmouth. Tyrannical as he is, he never thinks of the tortures of fanny both physical and mental which she is undergoing at Portsmouth. Sir Thomas is under an illusion that what ever he thinks is correct, is consequently useful. His eyes are opened by the elopement of Mrs. Rushforth and of Julia little later on. It is now abundantly clear to him as to what this repression towards his daughters has caused them. He is not tyrannical in the literal sense of the word but tyrannical in the sense that his good intentions have brought about bad results. He never considered his restraint and repression exercised on his children as bad. He is, in fact, an anxious father but has never shown outward affection and warmth of love for his children. The reserve of his manner towards his daughters ' repressed all the flow of his children's spirits before him'.

Sir Thomas receives harsh treatment at the hands of the author towards the end. He has committed a serious wrong in respect of the education of his daughters and of Fanny and he deserves the treatment given to him at the end: 'Sir Thomas, poor Sir Thomas, a parent, and conscious of errors in his conduct as a parent, was the longest to suffer. He felt that he ought not to have allowed the marriage the excessive indulgence and flattery of their aunt had been continually contrasted with his own severity': that it had been the most direful mistake in his plan of education (Ibid, ch.48, p.752-3). Sir Thomas also realizes that his daughters were also instructed theoretically in their religion but 
never required them to bring into daily practice. The harshness of treatment is allied with sympathy with Sir Thomas. Jane calls him 'poor Sir Thomas '. Along with harsh treatment, he receives greater attention of the author, greater than any father figure probably receives. He is a prominent figure in the central theme o Mansfield Park i.e. education. Jane Austen also speaks through Sir Thomas Bertram when the latter defined the duties of a clergyman (Chapman, 1970, p.113), which are contrasted with the duties of the clergy defined with Northanger Abbey: "parish has wants and claims which can be known only by a clergyman constantly resident... He (Edmund) knows that human nature needs more lessons than a weekly sermon can convey and that if he doesn't live among parishioners, and proves himself by constant attention their well-wisher and friend, he does very little for their good or his own'(Mansfield Park,ch.25.p.619).

For all of his flaws, Sir Thomas does learn from his mistakes, although he probably does not learn that his parenting style is partially what caused the problems. He realizes that he was not an effective parent when he sees his children's mistakes. Following Maria's engagement, he realizes that he was too distant a parent. By the time he cared enough to care, his children were too old to be influenced. Tom Bertram has become a wastrel (and only a brush with death changes him), and Maria and Julia are vain and idle. Sir Thomas sees Fanny, her brother William, and her sister Susan as being moral people because they have been exposed to hardship early in life, which has had a positive effect on their lives that has withstood bad parenting (Wiesenfarth, 1967, p. 106). His banishment of Maria for eloping with Henry Crawford even though she was married and Mrs. Norris because he sees how destructive she has been to his family, coupled with his embracing of Fanny as a daughter even before she marries Edmund, shows that he is changed. He has become a moral person, even if he will probably always remain an authoritarian parent.

Sir Bertram is the best picture of an uncomprehending parent. He is drawn with greater vitality on the part of the author. Though his blunder is worse than that of Bennet, he feels responsibility and is more repentant over his blunder than the non-serious type of the person, Mr. Bennet is. He exercises greater authority over his wife than Bennet and that hen-pecked husband, John Dashwood. He is less mercenary than General Tilney. He possesses gift of speech of Sir Walter Eliot but is wiser than an utterly foolish man like Sir Walter. He is a more robust than weakling Woodhouse. He is in fact the best creation of Austen as a father figure.

Permissive-indulgent parents are highly involved with their children, but they place few demands or controls on them. Children of these parents are very spoiled and immature; they do not learn respect for others and have difficulty controlling their behavior.

In Mr. Woodhouse, we have an affectionate and indulgent father. He is a widower. It is only in two of her novels that Jane Austen has shown both the living parents i.e. in Pride and Prejudice and Mansfield Park. Mr. Woodhouse is a valetudinarian all his life, without activity of his body and mind and looks much older in many ways other than years. Invalid as he is, he has developed a sort of allergy against matches, weddings and matrimonial affairs owing to, what the author terms, 'gentle selfishness'. As an invalid, he takes his privileges to enjoy the company of his near and dear ones. Matches are silly things; break up one's family circle grievously (Emma.ch.1, p.768). He dislikes the wedding cake party because of its association with marriage and partly because it is not agreeable to his stomach. He is surprised that the whole cake was eaten up; he is taken a back to hear that even Mr. Perry's children did grab pieces of the same cake. But he believes it to be a rumor only: he has an aversion for all out-door activities and he would therefore invite people to his own house and that also on his own terms. His nervousness is another mark of his character. The idea of sitting for his pictures makes him nervous. A little quickness of Mr. Elton's voice hurt him. He gets nervous when he hears some strange and unknown voices. Eight persons at a dinner is the maximum number of people his nerves can bear. Marriages of his dear ones make him, of course, shockingly nervous. Late parties also strain his nerves. It is only shining galore of warming fire, even during summer, that makes him cosy and comfortable.

The simplicity of his mind is striking. Emma, we are told, dearly loves her father but he is no companion for her as he would not meet her in conversation, rational or playful. Mr. knightly presents him, 'Books of engravings, drawers of medals, cameos, corals, shells and every other family collection within his cabinets (Ibid, ch42, p.984), for his entertainment. He is exceedingly amused at these objects. He does possess childish taste. He has childish fondness for charades and often recites: 'kitty, a fair but frozen maid'. Emma rules supreme in the house and his invalid father never intervenes. Robert Liddell rightly points out that 'Emma managed to do what she really wanted - to marry Mr. Knightly and to go to the sea, in spite of her father' (Liddell, 1969, p.114); Mr. Woodhouse doesn't exercise any restraint on Emma's liberty to do as she likes. She herself doesn't like, in the beginning particularly, the idea of marriage for the simple reason that she has apprehension of loosing her independence which she enjoys at Hartfield. Mr. Woodhouse is, therefore, 'not a nuisance' for Emma.

Mr. Woodhouse does have a weakness in him but the writer, instead of evincing indignation against him, shows deep 
sympathy with Mr. Woodhouse. The reader equally enjoys the foibles of Mr. Woodhouse. Jane Austen rarely shows her impatience with her characters possessing certain weakness. Mr. Woodhouse is in no way nuisance for his social circle. He is 'loved for friendless of his heart and his amiable temper' (ch.1, p.764). Miss Bates, who is not sometimes agreeable to some people because of her irrelevant talk, is quite agreeable to Mr. Woodhouse because her talk on little matters, her trivial communication and harmonious gossip "quite suited Mr. Woodlouse's simple temper". He is highly courteous to ladies in particular as Emma says: "he loves any thing of the sort (charade) and especially any thing that pays women a compliment. He has the tenderest spirit of gallantry towards us all"(Emma, ch.9.p.809). In his gentle behavior towards women folk, A.C. Bradley says; "Mr. Woodhouse is, next to Don Quixote, perhaps, the most perfect gentleman in fiction"(Wright,1972,p.157). Surrounded by his guests," according to his custom he is making a circle of his guests, and paying compliments to ladies" (Lascelles, 1968).

The restrictions on Emma, what ever they could be, are self-imposed and it is out of her own pity for her helpless father that she argues Mr. Knightly to settle at Hartfield after marriage. Mr. Woodhouse is still not happy with the idea. The author contrives wonderfully well: "Pilfering was house-breaking to Mr. Woodlouse's fears ... and, but for the sense of son-in-law's protection, would have been under wretched alarm every night of his life" (ch.55, p. 1060). R. W. Chapman in his book, Jane Austen, Facts and Problems. (p.123)quotes author's opinion, " that Mr. Woodhouse survived his daughter's marriage and kept her and Mr. Knightly at Donwell, about two years"(Memoir,ch.10). Mr. Woodhouse goes much farther in his involvement in Emma's life, even though he rarely leaves Hartfield. At the beginning of Emma, Austen writes that "she loved her father, but he was no companion to her. He could not meet her in conversation, rational or playful" (Emma 2). He is much older than she is, and practically an invalid. He is "a nervous man, easily depressed...hating change of any kind" (Emma 3). He never believes that people are any different from himself and tries to persuade others to live as he lives.

Mr. Woodhouse, like Mrs. Weston, sees nothing to fault in Emma. He will not hear of anyone criticizing her, not even Mr. Knightley, partially because Emma is his younger daughter and partially because Emma caters to him constantly. Even though Emma is the female head of Hartfield and wisely overrides her father when he tries to regulate what guests eat and what they do. Mr. Woodhouse dictates the lifestyle at Hartfield (Paris, 1978, p. 81). While some might feel that Mr. Woodhouse is not only egocentric (which he is) and an annoyance, something must be remembered: Emma indulges him as he indulges her. She does not think he is egocentric or an annoyance. Emma loves him dearly. The only time Mr. Woodhouse becomes a problem is when Emma realizes that she loves Mr. Knightley. Loving Mr. Knightley means marrying him. Mr. Woodhouse is so against change that Emma's marriage is going to cause him pain.

Mr. Woodhouse's view of marriage is clear: he thinks it is a calamity (Bush, 1975, p.140). Mrs. Weston is "poor Miss Taylor" because her marriage disrupts his household (Wiesenfarth, 1967, p. 113). He asks Emma to stop making matches (which she ignores), but not in such a way that suggests deep disapproval. Mr. Woodhouse has certainly not resigned himself to the thought that Emma might one day marry. Although with Emma insisting she will never marry, he need not worry. The news that Emma wishes to marry Knightley comes as not only a shock, but also a great disturbance to Mr. Woodhouse. He suggests that things remain the same, which is impossible. Emma will not discomfort her father, but she wants to marry Knightley because she understands that things cannot remain the same between them. Austen seems to want the reader to wish for Mr. Woodhouse's death for Emma's sake, although she would never want that (Paris, 1978, p. 67-68). In fact, Emma is the one who finally solves the problem by suggesting to her father that he would feel safer from the chicken thieves if there were a younger man in the house. Emma plays to one of her father's weakest spots (his fear of the outside world) to get what she desires.

In some ways, Mr. Woodhouse may seem like an indifferent parent--after all, he is fairly egocentric and does not care about the outside as long as it does not disturb his little world. Yet he cares for Emma, and he is overly involved in her life without placing limits or controls in her. Jane Austen, for all that she satirizes fools and shows them for what they are, is herself indulgent to Mr. Woodhouse. She seems to approve of the way Emma responds to his needs and wishes (Paris, 1978, p. 81). Part of the reason might be because Mr. Woodhouse, as the oldest of the parents, demands more attention to his needs because he cannot see to them himself, which reveals a softer side to Emma. Mr. Woodhouse is a unique creation. "The Valetudinarian Mr. Woodhouse, with his gruel, replaces the real invalid, Mr. Watson, who was also addicted to gruel and cards" (Liddell, 1969, p.92). The reader is greatly amused at idiosyncrasies and feels great sympathy for a helpless creature like him. "Poor Woodhouse little suspected what was plotting against him in the breast of that man (Knightly) whom he was so cordially welcoming"(Emma, ch.50, p.1028).

Sir Walter Eliot is another variation of a father figure. Conceited and silly as he is, he feels that Baronetcy and Beauty have harmoniously combined in him. He is always thinks of his personal appearance like women, "every woman's eye must be on him"(Persuasion, ch.15, p.1294), the modest Sir Walter is sure. He regrets that there are 
rather many 'plain' women in Bath. He is partial to Elizabeth and he himself shall bloom for ever - that age can't wither them nor custom stale their infinite variety. Sir Walter Elliot is arguably the vainest character Jane Austen ever created. This man, whose sole amusement in life is the continual reading of the Baronetage, is described in this way: "Vanity was the beginning and end of his character; vanity of person and situation. He had been remarkably handsome in his youth, and, at fifty-four, was still a very fine man." (Persuasion).

Sir Walter sees himself and his eldest daughter Elizabeth as unchanging in a world where everything around him ages and becomes uglier. Bath, where he takes financial refuge, is the perfect place for him. Bath is filled with social climbers who will respect both him and Elizabeth (Gooneratne, 1970, p.168). And Bath is concerned mainly with barren, meaningless social rituals (Lauber, 1993, p.103). Sir Walter cares little for Anne or his youngest daughter, Mary. They are plain, they are aging, and they are not a credit to his name or his image, even though Mary has married well. Sir Walter's world has no room for anything that is less than perfect or flattering to him. Sir Walter's indifference to Anne has been of long duration. It was only Lady Russell's intervention which prevented Anne from marrying. In the end, when Anne finally accepts Captain Wentworth, her father remains completely indifferent to her fate, since the man has some money and a decent-sounding name. Perhaps the most important thing to Sir Walter is that she will no longer be a burden on him. Sir Walter's neglect extends beyond his younger daughters. Following his wife's death, all economy died with her and not because he grieved for her. Sir Walter hides behind the Baronetage to block out the unpleasantness of the outside world, and his estate suffers for it. Kellynch-hall is his responsibility, and life's challenge to him; by not taking care of it the way he should, he shows that he does not measure up to life's demands (Wiesenfarth, 1967, p. 145).

In response to the realization that they cannot continue living the way they have been, Sir Walter decides to retrench, but only after rejecting Anne's suggestion of a strict living. Even when the decision is made to lease Kellynch-hall, Sir Walter is disinclined to lease it to a naval officer because he does not like their looks. He is the ultimate snob, concerned with nothing more than titles, rank, pedigree, and appearances (Lauber, 1993, p. 98). Sir Eliot has shallow pursuits. For his amusements, we are told, "he never took up any book but the 'Baronetage'; there he found occupation for an idle hour, and consolation in a distressed one"(Persuasion, ch.1, p.1211). He feels great pride in finding his name in the book. Vanity is, in fact, the beginning and end of his character - "vanity of person and situation". His sense of pride is injured when he comes to know that Mr. Eliot has married. As a head of the family, he feels he should have been consulted. But he is greatly satisfied when he is assured that Mrs. Eliot is a fine woman with a large fortune.

Chapman has rightly said: "Except Sense and Sensibility, we know or can infer a marked disparity, moral or intellectual or both between the partners"(1970, p.186). This is said about the heads of central families in the novel of Jane Austen. As such we find disparity between Sir Eliot and late Mrs. Walter Eliot. We are told, that 'there was method and moderation when his wife was there'(Persuasion, ch.1, p.1215). Sir Walter Eliot is now, economically, shattered as a result of his bestowing gifts to people and carrying on with charity with a view to satisfy his vanity. He is compelled by his economic conditions to retrench his Kellynch residence. He doesn't regret the retrenchment firstly, because he has got a house in Camden place, a house which he considers, quite becoming to a man of consequences like him, secondly, because his Kellynch lodge is let to an admiral of good breeding possessing good appearance unlike other naval officers who, as Sir Walter Eliot believes, grow old very quickly and possess no background.

Sir Eliot's treatment of Anne Eliot is that of an un-comprehending and unsympathetic parent. Mary Lascelles rightly indicate a second theme in the novel as we have: "the bursting open, for Anne, of the prison that Sir Walter and Elizabeth have made of Kellynch"(1968, p.181). It is partly because of Lady Russell's doings and partly because of Sir Walter Eliot's disapproval of Captain Wentworth's character that Anne failed to marry him. Sir Walter didn't approve Captain Wentworth on the ground that he had nothing except 'himself' to recommend and that he had no background. Anne is overlooked and ignored at Camden place too. 'They are happy to receive Anne for the sake of showing her the house' (ch.15, P. 1291). Elizabeth is disdainful and Sir Walter severe at Anne's friendship with Mrs. Smith. Mrs. Smith is looked upon as 'one of the five thousands Mrs. Smiths, whose names are to be met with every where' ... 'Miss Anne you have extraordinary tastes', says Sir Walter (ch. 17, P. 1304). Mr. and Mrs. Musgroves are clearly contrasted with Sir Walter Eliot. Musgroves are modest and free from any ambitious feelings with regard to the marriage of their children, where as Sir Walter's pride and ambition have brought about misery to his children, Anne being greater victim than Elizabeth, although the latter is a victim of her own choice. There is some similarity between Mansfield Park and Persuasion in the sense that Anne and Fanny are both victims of their un-comprehending parents. The only difference in their suffering is that, where as Fanny is subjected to grosser tyrannies on the part of her foster-parent, Anne suffers in a subtler way. In other words, whereas Sir Bertram takes an active part in inflicting sufferings on Fanny, Sir Eliot is rather passive. Jane Austen's satire is milder in 
Persuasion than it is in Mansfield Park. It is with the spirit of amusement that Sir Eliot has been treated by the author. With all his whims and fancies, he is not much to blame in comparison to Sir Bertram.

\section{Conclusion}

Jane Austen's study of the character both male and female is remarkable. She has greater insight into female character than male ones. Her male characters, however, are life-like. The six father figures are true to life and are a lively portrayal of country gentry of her time. They have an individuality of their own and they also represent their class. If they don't sufficiently represent their class, they nevertheless, cover larger population of country gentry which can easily be classed with them. Given the range of parenting styles, the heroines in Jane Austen's novels mature differently under their parents' tutelage. Some, obviously, mature faster and earlier than others for a variety of reasons. Jane Austen's heroines have different backgrounds, with a full range of parents. Yet all of them set out to accomplish and succeed at gaining what, in Austen's day, was considered the main purpose for young women. They all marry, and for the most part, they marry well. Most importantly, they marry for love. The Morlands may not have had much to do with Catherine's education, but they do not dissuade her from marrying Henry Tilney. Mrs. Dashwood encourages both of her daughters to marry for love, and Elinor certainly does. Whether or not Marianne does, it is clear that she has learned how dangerous "grand passion" can be. Mr. Woodhouse would rather not have Emma marry at all, but it is clear that she will get her way in the end. Mr. Bennet wants Elizabeth to marry for love and encourages her to do so even though his wife just wants her married. The Prices do not seem to care about Fanny, and by the end of Mansfield Park, she is too important to the Bertram family for them to mind that she will become a Bertram in fact by marrying Edmund. Sir Walter does not care whom Anne marries, and Lady Russell, although undoubtedly disappointed, will probably accept Anne's decision. The parents that these young women have play a major role in the choices that they make when they marry. The men the heroines marry see their future wives for all of the attributes these women acquire from their parents and, in some cases, from the men they love. Thus we see that the parents in general and the father figures in particular had a great impact on their children and played a significant role in the marriage of their daughters to some extent.

\section{References}

Alexander, Christine and Juliet, McMaster, eds. (2005). The child writer from Austen to Woolf.

Baumrind, D. (1989). Rearing competent children. In W. Damon (Ed.), Child development today and tomorrow (pp. 349-378). San Francisco: Jossey-Bass.

Baumrind, D. (1991). The influence of parenting style on adolescent competence and substance use. Journal of Early Adolescence, 11(1), 56-95.

Berendsen, Marjet.( 1991). Reading character in Jane Austen's Emma, Van Gorcum.

Berglund, Birgitta. (1993). Woman's whole existence: The house as an image in the novels of Ann Radcliffe, Mary Wollstonecraft, and Jane Austen, Lund University Press.

Bush, Douglas. (1975). Jane Austen, Macmillan.Cambridge: Cambridge University Press.

Chapman, R. W. (1970) Jane Austen: facts and problem, Oxford, Clarenden Press.

Chapman, R. W. ed. (1932); 2nd ed.(1952) Jane Austen's Letters to her sister Cassandra and others. Oxford: Clarendon.

Cecil, David, Lord. (1978). A portrait of Jane Austen, Constable.

Copeland, Edward and Juliet, McMaster, eds. (1997). The Cambridge Companion to Jane Austen. Cambridge: Cambridge University Press.

Gard, Roger. (1992). Jane Austen's novels: the art of clarity, Yale University Press.

Gooneratne, Yasmine. (1970). Jane Austen, Cambridge University Press.

Halperin, John. (1984).The life of Jane Austen, Johns Hopkins University Press.

Kaplan, Deborah. (1992). Jane Austen among women, Johns Hopkins University Press.

Kettle, Arnold, (1972). An Introduction to the English Novel, Vol.1, London: Hutchinson.

Lascelles, M. (1968). Jane Austen and her Arts, London: Oxford University Press.Lauber, John J .(1993). Jane Austen, (Twayne's English Authors Series) Twayne.

Le Faye, Deirdre. (2006). A Chronology of Jane Austen and her family 1600-2000. Cambridge: CUP.

Liddell, Robert. (1969). The Novels of Jane Austen, London: Longmans. 
Litz, A. Walton. (1965). Jane Austen: A Study of her Artistic development, London: Chatto and Windus.

Lynch, Deidre. (1998).The economy of character. Chicago: University of Chicago Press, ISBN 0-226-49820-4.

Miller, D. A. (2003). Jane Austen, or the secret of style. Princeton: Princeton University Press, ISBN 0-691-12387-X.

Mudrick, Marvin. (1952).Jane Austen; irony as defense and discovery, Princeton, Princeton University Press . Mukherjee, Meenakshi. (1991). Jane Austen, Macmillan.

Newman, Annie. (2009) "Family Dynamics in Jane Austen's Novels". The Republic of Pemberley. Retrieved Feb, 2010 from: http://www.pemberley.com/papers/famaust.htm

Paris, Bernard J. (1978). Character and conflict in Jane Austen's novels: a psychological approach, Wayne State University Press.

Smith, Ross S. (1978). Fanny Bertram: the structure of Mansfield Park, James Cook University.

Smith, LeRoy W. (1983). Jane Austen and the drama of woman, Macmillan.

Southam, B. C., ed. (1987). Jane Austen: the critical heritage, Vol. 2 1870-1940, Routledge \& K. Paul.

Southam, B.C. Ed. (1968). Critical essays on Jane Austen, London: Routledge and Kegan Paul. Sulloway, Alison G. (1989).Jane Austen and the province of womanhood, University of Pennsylvania Press.

Tilloston, Kathleen. (1962). Novels of Eighteen-Forties, London: Oxford University Press.

Tucker, George Holbert. (1983). A Goodly Heritage. Manchester: CarcanetReissued as A History of

Jane Austen's Family. Stroud: Sutton.

Wiesenfarth, Joseph. (1967).The errand of form; an assay of Jane Austen's art, Fordham

UniversityPress.

Williams, Michael. (1986). Jane Austen: six novels and their methods, Macmillan.

Wright, Andrew H. (1972). Jane Austen's Novels: A study in structure, Chatto \&Windus, Bucks. 